\title{
Biomass valorisation of Arundo donax L., Miscanthus $\times$ giganteus and Sida hermaphrodita for biofuel production**
}

\author{
Tajana Krička ${ }^{1}$, Ana Matin ${ }^{1}$, Nikola Bilandžija ${ }^{1}$, Vanja Jurišićc ${ }^{1}$, Alan Antonović ${ }^{2}$, Neven Voća ${ }^{1}$ \\ and Mateja Grubor ${ }^{1}$ \\ ${ }^{1}$ University of Zagreb Faculty of Agriculture, ${ }^{2}$ University of Zagreb Faculty of Forestry; \\ Svetošimunska cesta 25, 10000 Zagreb, Croatia \\ Received May 25, 2017; accepted October 12, 2017
}

\begin{abstract}
In the context of the growing demand for biomass, which is being encouraged by the EU directives on the promotion of the use of renewable energy, recent investigations have been increasingly focused on fast-growing energy crops. The aim of this study was to investigate the energy properties of three types of agricultural energy crops: Arundo donax L., Miscanthus $\times$ giganteus and Sida hermaphrodita. This investigation looked into the content of non-combustible and combustible matter, higher and lower heating values, lignocellulose content, and biomass macro-elements. The results indicate that the energy values of these crops are comparable, while their lignocellulose content shows significant variations. Thus, Arundo donax L. can best be utilised as solid biofuel due to its highest lignin content, while Miscanthus $\times$ giganteus and Sida hermaphrodita L. can be used for both liquid and solid biofuels production. As far as Arundo donax L. is concerned, a higher ash level should be taken into consideration.

Keywords: energy crops, energy values, chemical composition
\end{abstract}

\section{INTRODUCTION}

According to Directive 2009/28/EC, biomass is the biodegradable fraction of products, waste and residues of biological origin, derived from agriculture (including plant and animal substances), forestry and related industries, including the biodegradable fraction of industrial and municipal waste. Biomass production is directly associated with the use of soil, which must be sustainable. Sustainability is achieved when biomass production is $\mathrm{CO}_{2}$ negative or neutral during its life-cycle. In order to prevent the food versus energy competition when biomass production is concerned,

*Corresponding author e-mail: nbilandzija@agr.hr

**This research was funded by the Croatian Science Foundation, under project No. 3328, (2014-2018) 'Converting waste agricultural biomass and dedicated crops into energy and added value products - bio-oil and biochar production', and by the Ministry of Agriculture under the VIP project (2014-2018) 'The potential of energy crops Sida hermaphrodita on organic farm'. the RED (2009/28/EC) directive introduced the term 'sustainable biomass'. This term gained additional power and significance upon the EU Council decision (2016/590) to sign the Paris Climate Agreement.

While defining agricultural biomass, the term 'biofuel' is often used. Produced from biomass itself, biofuels can be divided into several types, in terms of the form of their end use and the type of raw material they are produced from. With respect to their end use, biofuels are classified as solid, liquid and gaseous.

Agricultural lignocellulose biomass carries a large energy potential because it is obtained from the residues of primary agricultural products and from food processing by-products (Krička et al., 2012). However, due to their low requirements when cultivated for biomass production, as well as their significant yield of biomass per hectare, perennial energy crops are being increasingly investigated. These crops are well-adapted for cultivation on marginal soils where they do not compete with food production. The establishing of such plantations in rural areas provides the opportunity to develop an independent renewable energy source and has positive influence on agricultural production.

These crops include Arundo donax L., Miscanthus $\times$ giganteus and Sida hermaphrodita. Arundo donax L. is an 8-9 metres high grass species that grows in dense stands. Its biomass yield depends on moisture content, density and time of cultivation, and can reach up to $30 \mathrm{t} \mathrm{ha}^{1}$. Arundo donax L. is adapted to a wide variety of ecological conditions, but it is generally associated with riparian and wetland systems. Several field studies have highlighted the beneficial effect of the crop on the environment, due to its minimal requirements with regard to soil tillage, as well as fertilizer and pesticide applications (Riffaldi et al., 2010).

(C) 2017 Institute of Agrophysics, Polish Academy of Sciences 
Miscanthus is a promising lignocellulosic feedstock with various applications, due to its rapid biomass accumulation in temperate climates. Miscanthus $x$ giganteus can reaches 4 metres in height, and its yields (with applied irrigation) can reach up to $40 \mathrm{t} \mathrm{ha}^{-1}$ (Clifton-Brown, 2001). The crop requires limited fertiliser application and very few other inputs, and it adds significant amounts of organic matter to the soil.

Sida hermaphrodita is a perennial crop that is 1-4.5 m high (mostly around $3 \mathrm{~m}$ ). Its yields can reach up to $25 \mathrm{t}$ ha $^{-1}$ (Denisiuk, 2006). Sida hermaphrodita belongs to the mallow family and is native to North America. It has hairy stems and leaves with toothed lobes. Plantations can be used for up to 25 years whereby the dry woody parts are harvested from late autumn until spring with high and stable yields. It is an easy-to-handle crop that can be cultivated with conventional farming methods and machinery.

Among the many biomass features, quality is determined by observing non-combustible and combustible properties. The most important indicators of biomass quality are the content of energy-carrying chemical bonds and of the most common elements (nitrogen, carbon, sulphur, hydrogen and oxygen), as well as the total ash content (Tao et al., 2012).

In order to use biomass as fuel in heat and electric energy generation, it is necessary to know its heating values, as they constitute a reliable measure for determining the energy content of fuel (Jenkins et al., 1998). This is often expressed as either higher or lower heating value. Higher heating values refer to the heat released in the complete combustion of a fuel volume unit which results in the generation of water vapour and its eventual condensation. At that point, the released energy is measured. Lower heating values do not consider the latent heat of the water contained in the fuel (Vargas-Moreno, 2012).

Biomass is a complex heterogeneous mixture of structural organic components, such as cellulose, hemicellulose and lignin. The characterisation of these components (regarding quality and quantity) in a given biomass is crucial for determining the approach to biomass processing (Antonović et al., 2016) and for understanding the biofuel reaction mechanism in its production. Biomass quality is crucial for usability, and it is often connected with the content of various micro- and macro-elements. Such biomass elemental content is commonly influenced by genetically determined properties, as well as by environmental conditions, such as soil characteristics (fertility, $\mathrm{pH}$ ), weather features (precipitations) and plant growing measures mainly fertilization (Barglowicz, 2014). Knowledge on the content of different elements in biomass may be useful in choosing the method of transforming biomass into energy (Barglowicz, 2014; Borkowska and Lipiński, 2008).

Therefore, the aim of this work was to investigate the energy properties of the Arundo donax L., Miscanthus $\times$ giganteus and Sida hermaphrodita crops, and to define which crop had the best performance in terms of production of solid or liquid fuels. The investigations encompassed both non-combustible and combustible properties of biomass, as well as its heating value, lignocellulose content and macro-elements content.

\section{MATERIALS AND METHODS}

Three rapidly-growing energy crops, i.e. Arundo donax L., Miscanthus $\times$ giganteus and Sida hermaphrodita, were investigated. The crops were cultivated in Zagreb and Zagreb County, i.e. in the western part of Croatia. The soil at all three sites was slightly acidic (with the average amount of $\mathrm{pH}\left(\mathrm{H}_{2} \mathrm{O}\right)$ ranging from 5.39 to 6.53$)$, while the percentage of organic matter ranged from 1.53 to 2.13 , the nitrogen content from 0.09 to 0.17 , the amount of phosphorus $\left(\mathrm{P}_{2} \mathrm{O}_{5}\right)$ from 2.32 to $8.98 \mathrm{mg} 100 \mathrm{~g}^{-1}$ of soil, and potassium $\left(\mathrm{K}_{2} \mathrm{O}\right)$ from 10.6 to $22.0 \mathrm{mg} 100 \mathrm{~g}^{-1}$ of soil. Plantations of the investigated crops were grown using classical agrotechnics, without fertilization and irrigation. The harvest was carried out in February 2017 when the plants were four years old (with the average air temperature at the harvested time being $-15^{\circ} \mathrm{C}$ ). In our research, non-combustible and combustible properties, heating value, lignocellulose composition and macro-element content were investigated. The following methods were used: moisture content, i.e., dry matter content (HRN EN 18134-2:2015), was measured in a laboratory dryer (INKO, Croatia), nitrogen content (HRN EN ISO 16948:2015) was measured in an elementary analyser Vario MACRO (Elementar, Germany), ash content (HRN EN ISO 18122:2015) and coke content (CEN/TS 15148:2009) were measured in a muffle furnace (Nabertherm, USA), while fixed carbon content (EN 15148:2009) were measured by computed derivation. What is more, carbon and hydrogen content (HRN EN ISO 16948:2015) and sulphur content (HRN EN ISO 16994:2015) were measured in a CHNS analyser (Elementar, Germany), oxygen and residues of elements $\mathrm{C}, \mathrm{H}, \mathrm{N}, \mathrm{S}$ were determined by computed derivation, while volatile matter content was measured according to EN 15148:2009. The higher heating value was determined by the EN 14918:2010 method, in an adiabatic calorimeter (IKA, Germany), while the lower heating value was obtained by computed derivation.

Determination of cellulose, hemicellulose and lignin content was conducted by the modified standard method ISO 5351-1:2002 in laboratory conditions. Finally, the quantity of macro-elements (sodium, magnesium, potassium and calcium) in the samples was determined by HRN EN ISO 16967:2015 methods - in an atomic absorption spectrometer (Perkin Elmer, Analyst 400), with the samples previously prepared in a microwave oven (HRN EN 16968:2015).

The data were analysed by means of the statistical software package SAS version 9.3 (USA). 


\section{RESULTS AND DISCUSSION}

The non-combustible and combustible properties of the Arundo donax L., Miscanthus $\times$ giganteus and Sida hermaphrodita crops are shown in Tables 1 and 2.

Since the environmental air temperature during the winter season of $2016 / 2017$ was unusually low (up to $-15^{\circ} \mathrm{C}$ ), all three crops (Arundo donax L., Miscanthus $\times$ giganteus and Sida hermaphrodita) had exceptionally low moisture content per mass after the harvest, which is a good precondition for safe storage (Francescato et al., 2008). Thus, the dry matter quantity of the experimental crops is very high, ranging between 87.52 and $92.7 \%$. A comparison of the obtained results with literature references (Howaniec and Smolinski, 2011; Jegurim et al., 2010) corroborates the obtained moisture values and dry matter values obtained for the Arundo donax L., Miscanthus $\times$ giganteus and Sida hermaphrodita crops.

Ash content is one of the main factors of biomass quality, since higher amounts of ash diminishes the quality of fuels, especially solid ones. According to Jeguirim et al. (2010), the ash content in Arundo donax L. is 5.0\%, while our investigation found a somewhat lower value of $3.56 \%$. The above authors also state that the ash content of Miscanthus $\times$ giganteus is $2.7 \%$, while in Howaniec and Smolinski (2011), it was determined at $1.60 \%$, i.e. slightly above $1.20 \%$ - the value found in our investigation. Stolarski et al. (2014) hold that the ash content of Sida hermaphrodita is $2.56 \%$, while our investigation revealed a slightly higher value (2.84\%). Vassilev et al. (2010) state that the ash content in agricultural biomass goes up to $18 \%$. The values of ash content in the biomass of the investigated crops (Arundo donax L., Miscanthus $\times$ giganteus and Sida hermaphrodita) also point to their high quality.

Coke content and fixed carbon content are considered positive properties of biomass because they represent the quantity of energy released by the combustion of a specific amount of biomass (Garcia et al., 2012; Jurišić et al., 2017). In our study, the obtained fixed carbon content in Arundo donax L. was $11.37 \%$, which is lower than $18.4 \%$ - the amount found by Jegurim et al. (2010). In Miscanthus $\times$ giganteus, we saw a fixed carbon value of $10.01 \%$, which is consistent with literature references, wherein Jegurim (2010) states a value of 9.5\%, and Howaniec and Smolinski (2011) reveal a value of $11.62 \%$. We also determined a fixed carbon content in Sida hermaphrodita at 5.09\% which is significantly below $17.14 \%$ - the value obtained by Howaniec and Smoliński (2011).

From an ecological point of view, nitrogen and sulphur contribute to the increase in greenhouse gases, and are considered to be unfavourable elements in biomass. Licursi et al. (2015) investigated nitrogen in the energy crop Arundo donax L., determining its content at around $0.3 \%$, while Jegurim et al. (2010) state a sulphur content of $0.2 \%$. The values obtained in this investigation are somewhat higher

Table 1. Non-combustible matter content in the Arundo donax L., Miscanthus $\times$ giganteus and Sida hermaphrodita crops

\begin{tabular}{|c|c|c|c|c|c|}
\hline \multirow{2}{*}{ Sample } & Moisture & Ash & Coke & Fixed carbon & Nitrogen \\
\hline & \multicolumn{5}{|c|}{$(\%$, mass $)$} \\
\hline Arundo donax L. & $9.01 \mathrm{~b} \pm 0.571$ & $3.56 \mathrm{a} \pm 0.216$ & $13.18 \mathrm{a} \pm 0.087$ & $11.37 \mathrm{a} \pm 0.202$ & $0.74 a \pm 0.020$ \\
\hline $\begin{array}{l}\text { Miscanthus x } \\
\text { giganteus }\end{array}$ & $12.49 \mathrm{a} \pm 0.520$ & $1.20 \mathrm{c} \pm 0.110$ & $11.24 \mathrm{~b} \pm 0.130$ & $10.01 b \pm 0.170$ & $0.23 \mathrm{c} \pm 0.014$ \\
\hline Sida hermafrodita & $7.22 \mathrm{c} \pm 0.140$ & $2.84 b \pm 0.131$ & $7.85 \mathrm{c} \pm 0.061$ & $5.09 \mathrm{c} \pm 0.061$ & $0.65 b \pm 0.045$ \\
\hline
\end{tabular}

Different letters within a column indicate significant differences at the $5 \%$ level.

Tab le 2. Combustible matter content, and higher and lower heating values of the Arundo donax L., Miscanthus x giganteus and Sida hermaphrodita crops

\begin{tabular}{|c|c|c|c|c|c|c|c|}
\hline \multirow{2}{*}{ Sample } & Carbon & Sulphur & Hydrogen & Oxygen & $\begin{array}{l}\text { Volative } \\
\text { matter }\end{array}$ & HHV & LHV \\
\hline & \multicolumn{5}{|c|}{$(\%$, mass $)$} & \multicolumn{2}{|c|}{$\left(\mathrm{MJ} \mathrm{kg}^{-1}\right)$} \\
\hline Arundo donax L. & $\begin{array}{l}45.67 \mathrm{c} \\
\pm 0.045\end{array}$ & $\begin{array}{c}0.29 \mathrm{a} \\
\pm 0.001\end{array}$ & $\begin{array}{c}6.17 \mathrm{a} \\
\pm 0.030\end{array}$ & $\begin{array}{l}47.13 \mathrm{a} \\
\pm 0.004\end{array}$ & $\begin{array}{l}76.06 \mathrm{c} \\
\pm 0.151\end{array}$ & $\begin{array}{l}17.48 \mathrm{~b} \\
\pm 0.060\end{array}$ & $\begin{array}{l}16.14 \mathrm{~b} \\
\pm 0.060\end{array}$ \\
\hline $\begin{array}{l}\text { Miscanthus } x \\
\text { giganteus }\end{array}$ & $\begin{array}{l}48.00 \mathrm{~b} \\
\pm 0.800\end{array}$ & $\begin{array}{c}0.18 \mathrm{c} \\
\pm 0.004\end{array}$ & $\begin{array}{c}6.21 \mathrm{a} \\
\pm 0.030\end{array}$ & $\begin{array}{l}45.34 b \\
\pm 0.781\end{array}$ & $\begin{array}{l}88.76 \mathrm{a} \\
\pm 0.170\end{array}$ & $\begin{array}{l}18.15 \mathrm{a} \\
\pm 0.060\end{array}$ & $\begin{array}{l}16.79 \mathrm{a} \\
\pm 0.060\end{array}$ \\
\hline $\begin{array}{l}\text { Sida } \\
\text { hermafrodita }\end{array}$ & $\begin{array}{l}50.08 \mathrm{a} \\
\pm 0.425\end{array}$ & $\begin{array}{c}0.23 \mathrm{~b} \\
\pm 0.021\end{array}$ & $\begin{array}{c}6.10 \mathrm{~b} \\
\pm 0.013\end{array}$ & $\begin{array}{l}42.95 \mathrm{c} \\
\pm 0.373\end{array}$ & $\begin{array}{l}84.90 b \\
\pm 0.329\end{array}$ & $\begin{array}{l}18.13 \mathrm{a} \\
\pm 0.087\end{array}$ & $\begin{array}{l}16.80 \mathrm{a} \\
\pm 0.090\end{array}$ \\
\hline
\end{tabular}

Explanations as in Table 1. 
and amount to $0.75 \%$ for nitrogen and to $0.29 \%$ for sulphur. Such divergences also appear in the investigations regarding the Miscanthus $\times$ giganteus biomass conducted by Jegurim et al. (2010), wherein nitrogen was $1.1 \%$, and sulphur was $0.2 \%$, while Bilandžija et al. (2016) found the nitrogen content to range from 0.20 to $0.54 \%$, and sulphur to be between 0.07 and $0.08 \%$, depending on the harvest time. Our investigation, which found a nitrogen content of $0.27 \%$ and a sulphur content of $0.18 \%$, corroborates with the conclusions drawn by Bilandžija et al. (2016). Howaniec and Smolinski (2011) determined the nitrogen and sulphur contents in the biomass of Sida hermaphrodita to be at rather low levels, i.e. nitrogen at $0.01 \%$ and sulphur at $0.04 \%$, while Šiaudinis et al. (2015) determined nitrogen to be at $0.75 \%$, and sulphur at $0.17 \%$, respectively. Our investigations fall within the scope of these literature references, with nitrogen reaching $0.65 \%$, and sulphur $0.23 \%$.

In the combustion process, biomass is decomposed into volatile gases and solid residue. Herein, a high percentage of volatile matter is one of the biomass characteristics (around 80\%) decreasing its energy value (Grubor et al., 2015; Quaak et al., 1999). The results of the investigations in all three energy crops are consistent with literature references and also corroborate high volatile matter content, with values ranging from 76.1 to $88.8 \%$. The biomass energy value is also negatively influenced by oxygen content. Licursi et al. (2015) determined the oxygen content at 49.2\% in Arundo donax L., while our investigation saw an oxygen value of $47.1 \%$. Jegurim et al. (2010), Howaniec and Smolinski (2011) and Bilandžija et al. (2016) investigated oxygen content in Miscanthus $\times$ giganteus biomass, and saw values ranging from 31.3 to $49.3 \%$. The oxygen value of $46.3 \%$, obtained in our investigation, is within the aforementioned value spread. Investigating the oxygen content of Sida hermaphrodita, Howaniec and Smolinski (2011), as well as Šiaudinis et al. (2015), obtained values between 35.7 and $41.9 \%$, which was consistent with the value of $43 \%$ obtained in our investigation. Carbon is the main and most important element in all types of fuels, and its content determines their quality, i.e. higher levels of carbon increase fuel quality. Carbon and hydrogen constitute the basic composition of each fuel, and increased carbon levels enhance fuel quality (Vassilev et al., 2010). As regards Arundo donax L., the values of carbon and hydrogen obtained by Licursi et al. (2015) were 44.8\%, for carbon and $6.0 \%$ for hydrogen, which is consistent with the results obtained in our investigation, amounting to $45.7 \%$ for carbon and to $6.13 \%$ for hydrogen. As regards Miscanthus $\times$ giganteus, our result for carbon is $47.0 \%$, and for hydrogen $6.21 \%$. These results are similar to those obtained by Jegurim et al. (2010), where oxygen was $43.7 \%$ and hydrogen was $5.7 \%$, by Howaniec and Smoliński (2011), where oxygen was $53.7 \%$, and hydrogen was $6.6 \%$, and also by Bilandžija et al. (2016), who found carbon to be between 46.5 and $50.1 \%$, and hydrogen to range from 3.57 to $4.15 \%$. The content of carbon and hydrogen in the Sida hermaphrodita energy crop were 50.1 and $6.10 \%$, respectively. These values are slightly higher than those referred to in literature. More specifically, Šiaudinis et al. (2015) determined the values for oxygen at $45.5 \%$ and hydrogen at $5.61 \%$, while Howaniec and Smolinski (2011) saw carbon and hydrogen content of 47.2 and $5.7 \%$, respectively.

The higher heating value (HHV) and the lower heating value (LHV) in Arundo donax L. amounted to 17.5 and $16.1 \mathrm{MJ} \mathrm{kg}^{-1}$, respectively. These results are consistent with those obtained by Jeguirim et al. (2010), who determined the $\mathrm{HHV}$ at $17.2 \mathrm{MJ} \mathrm{kg}^{-1}$, while Dahl and Obernberger (2004) saw an HHV of $19.8 \mathrm{MJ} \mathrm{kg}^{-1}$. As regards Miscanthus $\times$ giganteus, the investigated HHV was $18.2 \mathrm{MJ} \mathrm{kg}^{-1}$, and LHV was $16.8 \mathrm{MJ} \mathrm{kg}^{-1}$. Similar investigations were conducted by Jegurim et al. (2010) and Mos et al. (2013), who saw higher heating values ranging from 17.8 to $18.8 \mathrm{MJ} \mathrm{kg}^{-1}$, and lower heating values between 16.6 and $17.5 \mathrm{MJ} \mathrm{kg}^{-1}$. Hence, the results of our investigation corroborate with the previous ones. With regard to the heating values of Sida hermaphrodita, we saw an HHV of $18.1 \mathrm{MJ} \mathrm{kg}^{-1}$, and a LHV of $16.8 \mathrm{MJ} \mathrm{kg}^{-1}$. Stolarski et al. (2014) investigated the higher heating value of Sida hermaphrodita and obtained a value of $18.9 \mathrm{MJ} \mathrm{kg}^{-1}$, while Jurišić et al. (2017) saw an HHV of $17.9 \mathrm{MJ} \mathrm{kg}^{-1}$, which is in line with the results obtained in this investigation.

The lignocellulose composition of the investigated energy crops is shown in Table 3. In order to identify which energy crop best performs in the production of specific types of fuel, it is necessary to define hardness, biodegradability and combustibility of biomass on the basis of lignocellulose content (Olsen and Plackett, 1999). Lignocellulose consists of three components: lignin, cellulose and hemicellulose, and their content significantly varies in different types of biomass (Jørgensen et al., 2007). If lignocellulose contains more lignin, it is more suitable for direct combustion (Hodgson et al., 2010), while higher cellulose and hemicellulose contents make it more suitable for liquid fuel production (Lewandowski et al., 2003).

Table 3. Lignocellulose composition of the Arundo donax L., Miscanthus $\times$ giganteus and Sida hermaphrodita crops

\begin{tabular}{lccc}
\hline \multirow{2}{*}{ Sample } & Cellulose & Hemicellulose & Lignin \\
\cline { 2 - 4 } & \multicolumn{3}{c}{$(\%$, mass $)$} \\
\hline Arundo donax L. & $\begin{array}{l}\text { 43.56b } \\
\pm 0.018\end{array}$ & $\begin{array}{l}12.94 \mathrm{c} \\
\pm 0.012\end{array}$ & $\begin{array}{l}33.65 \mathrm{a} \\
\pm 0.021\end{array}$ \\
& & $19.30 \mathrm{~b}$ & $28.39 \mathrm{~b}$ \\
Miscanthus $\mathrm{x}$ & $49.27 \mathrm{a}$ & \pm 0.13 & \pm 2.620 \\
giganteus & \pm 0.120 & $27.21 \mathrm{a}$ & $26.38 \mathrm{c}$ \\
& & \pm 0.231 & \pm 0.732 \\
\hline Sida & $40.12 \mathrm{c}$ & & \\
\hline
\end{tabular}

Explanations as in Table 1. 
Table 4. Macro-elements quantities in the Arundo donax L., Miscanthus $\times$ giganteus and Sida hermaphrodita crops

\begin{tabular}{lcccc}
\hline \multirow{2}{*}{ Sample } & Sodium & Magnesium & Potassium & Calcium \\
\cline { 2 - 5 } & & \multicolumn{3}{c}{$\left(\mathrm{mg} \mathrm{kg}^{-1}\right)$} \\
Arundo donax L. & $113.3 \mathrm{~b} \pm 4.4$ & $496.0 \mathrm{a} \pm 3.9$ & $1055.7 \mathrm{a} \pm 7.5$ & $1570.4 \mathrm{~b} \pm 96.5$ \\
Miscanthus x giganteus & $90.0 \mathrm{c} \pm 0.2$ & $478.6 \mathrm{~b} \pm 0.6$ & $819.3 \mathrm{c} \pm 4.6$ & $1615.4 \mathrm{~b} \pm 7.7$ \\
Sida hermafrodita & $138.8 \mathrm{a} \pm 0.5$ & $494.7 \mathrm{a} \pm 2.0$ & $956.9 \mathrm{~b} \pm 9.1$ & $3222.0 \mathrm{a} \pm 66.7$ \\
\hline
\end{tabular}

Explanations as in Table 1.

Raspolli Galletti et al. (2015) investigated the lignocellulose content of Arundo donax L., and determined the following contents: cellulose $-41.6 \%$, hemicellulose $-23.6 \%$ and lignin $-24.6 \%$. The results obtained in our investigation are consistent in terms of cellulose content $(43.6 \%)$, but not in terms of hemicellulose $(12.9 \%)$ and lignin (33.7\%). The lignocellulose content of Miscanthus $\times$ giganteus was investigated by Wróblewska et al. (2009) with the following results: cellulose $-43.2 \%$, hemicellulose $-25.2 \%$ and lignin $-23.0 \%$, while Collura et al. (2005) determined the cellulose content to be at $45 \%$, hemicellulose at $30 \%$ and lignin at $21 \%$. Our investigation results are partly in line with the aforementioned, and they showed the following contents: cellulose $-49.3 \%$, hemicellulose $19.3 \%$, and lignin $-28.4 \%$. The lignocellulose content of Sida hermaphrodita was also investigated by Wróblewska et al. (2009), who determined the contents of cellulose at $41.0 \%$, hemicellulose at $17.1 \%$ and lignin at $26.0 \%$. Our investigations only partly corroborate the literature references, with cellulose content of $40.1 \%$, hemicellulose content of $27.2 \%$ and lignin content of $26.4 \%$. Such significant differences in the investigated lignocellulose biomass are to be expected because lignocellulose content is influenced by soil, location and harvest time (Barglowicz, 2014; Bilandžija et al., 2016; Lewandowski et al., 2003; Olsen and Plackett, 1999).

Quantity of macro-elements in the investigated crops are shown in Table 4. The macro-elements that are most commonly found in biomass are sodium, magnesium, potassium and calcium. These elements, together with micro-elements and ash, emerge during the biomass combustion process, and they may cause large slag formations and corrosion in furnaces (Bilandžija et al., 2016; Cassida et al., 2005). The macro-elements obtained for Arundo donax L. were investigated by Dahl and Obernberger (2004) who found $331,1627,6497$, and $3255 \mathrm{mg} \mathrm{kg}^{-1}$ of sodium, magnesium, potassium and calcium, respecitvely. In our investigation, significantly lower values were observed, with sodium quantity, magnesium, potassium, and calcium of 113,496 , 1055 , and $1570 \mathrm{mg} \mathrm{kg}^{-1}$, respectively. It can be assumed that such a major difference is caused by the quality of soil during cultivation and the harvest time. Macro-elements in Miscanthus $\times$ giganteus were investigated by Bilandžija et al. (2016), where the elements were found in the following ranges: $63.9-85.0 \mathrm{mg} \mathrm{kg}^{-1}$ sodium, $467.7-482.3 \mathrm{mg}$ $\mathrm{kg}^{-1}$ magnesium, $833.6-887.2 \mathrm{mg} \mathrm{kg}^{-1}$ potassium, and 1802 $-1956 \mathrm{mg} \mathrm{kg}^{-1}$ calcium, depending on harvest time. Similar results were obtained in our investigation, with sodium, magnesium, potassium, and calcium at: 90, 478, 819, 1615 $\mathrm{mg} \mathrm{kg}{ }^{-1}$, respectively. Krzywy-Gawrońska (2012) also investigated the macro-elements in Sida hermaphrodita and determined the content of magnesium at $740 \mathrm{mg} \mathrm{kg}^{-1}$, potassium at $3860 \mathrm{mg} \mathrm{kg}^{-1}$ and calcium at $5800 \mathrm{mg} \mathrm{kg}^{-1}$. These numbers are not consistent with our results for sodi$\mathrm{um}-139 \mathrm{mg} \mathrm{kg}^{-1}$, magnesium - $495 \mathrm{mg} \mathrm{kg}^{-1}$, potassium $-957 \mathrm{mg} \mathrm{kg}^{-1}$ and calcium $-3222 \mathrm{mg} \mathrm{kg}^{-1}$.

\section{CONCLUSIONS}

Based on our investigation of the energy characteristics of the fast-growing energy crops, i.e. Arundo donax L., Miscanthus $\times$ giganteus and Sida hermaphrodita, harvested in the winter season of 2017, the following conclusions can be drawn:

1. Non-combustible properties (moisture, ash, coke, fixed carbon and nitrogen) display differences, depending on the specific crop observed. The moisture content in the biomass of all investigated crops was exceptionally low. Ash, as an indicator of fuel quality, was also low, which underlines the good quality of the investigated biomass in relation to other agricultural crops. The coke and fixed carbon content are somewhat lower than expected, while the nitrogen content is somewhat higher or within the expected limits in all three investigated crops.

2. Combustible properties (carbon, sulphur, hydrogen, oxygen and volatile matters) also vary from one investigated crops to another. The contents of carbon and hydrogen, which are the major and most important elements in all types of fuels, indicate high quality of the investigated biomass. The contents of sulphur and oxygen, which are negative components, are low. The content of volatile matter, being another negative feature, diminishes the energy value of biomass, and is considered somewhat higher. The higher heating value was ranged from 17.48 to $18.15 \mathrm{MJ} \mathrm{kg}^{-1}$, while the lower heating value was between 16.14 and $18.80 \mathrm{MJ} \mathrm{kg}^{-1}$, which is an indication of high energy potential. 
3. The biomass lignocellulose content was determined on the basis of the percentage of cellulose, hemicellulose and lignin, and it was shown to vary, depending on the crop, indicating the possibility of using the investigated biomass for different types of biofuels.

4. The quantity of macro-elements (sodium, magnesium, potassium and calcium) vary in relation to crop biomass, and the determined values indicate that the investigated biomasses hold high combustion suitability and quality. The cumulative analysis of the results confirms that agricultural biomass is heterogeneous (in terms of its chemical properties), and this also applies to the fast-growing energy crops investigated in this study. Arundo donax L. would be more suitable for direct combustion as solid fuel, while Miscanthus $\times$ giganteus and Sida hermaphrodita show the potential of solid and liquid fuels production.

Conflict of interest: The Authors do not declare conflict of interest.

\section{REFERENCES}

Antonović A., Krička T., Matin A., Jurišić V., Bilandžija N., Voća N., and Stanešić J., 2016. Biochar quantification and its properties in relation to the raw material. Proc. 51st Croatian and 11th Int. Symp. Agriculture, February 15-18,Opatija, Croatia.

Barglowicz J., 2014. Content of chosen macroelements in biomass of Virginia mallow (Sida hermaphrodita Rusby). J. Cent Eur Agr, 15, 0-0.

Bilandžija N., Jurišić V., Voća N., Leto J., Matin A., Sito S., and Krička T., 2016. Combustion properties of Miscanthus $\mathrm{x}$ giganteus biomass - Optimization of harvest time. J. Energy Institute (in press), Available online, May, http:// doi.org/10.1016/j.joei.2016.05.009.

Borkowska H. and Lipiński W., 2008. Comparison of content of selected elements in biomass of Sida hermaphrodita grown under various soil conditions (in Polish). Acta Agrophysica, 11(3), 589-595.

Cassida K.A., Muir J.P., Hussey M.A., Read J.C., Venuto B.C., and Ocumpaugh W.R., 2005. Biofuel component concentrations and yields of switchgrass in South central US environments. Crop Sci., 45, 682-692.

CEN/TS 15148:2009. Solid biofuels - Method for the determination of the content of volatile matter. European Committee for Standardization.

Clifton-Brown J.C., Lewandowski I., Andersson B., Basch G., Christian D.G., Kjeldsen J.B., Jørgensen U., Mortensen J.V., Riche A.B., Schwarz K.U., Tayebi K., and Teixeira F., 2001. Performance of 15 Miscanthus genotypes at five sites in Europe. Agron. J., 93, 1013-1019.

Collura S., Azambre B., and Weber J.V., 2005. Thermal behaviour of Miscanthus grasses, an alternative biological fuel. Environ. Chem. Lett., 3, 95-99.

Dahl J. and Obernberger I., 2004. Evaluation of the combustion characteristics of four perennial energy crops (Arundo donax, Cynara cardunculus, Miscanthus $x$ giganteus and Panicum virgatum). 2nd World Conf. Biomass for Energy, Industry and Climate Protection, May, 10-14, Rome, Italy.
Denisiuk W., 2006. Plant production as a source of energy raw materials. Inżynieria Rolnicza, 5, 123-131.

Francescato V., Antonini E., and Bergomi L.Z., 2008. A handbook on biomass fuels. North-west Croatia Regional Energy Agency, Zagreb.

EN 15148:2009. Solid biofuels - Determination of the content of volatile matter, European Committee for Standardization.

EN 14918:2010. Solid biofuels - Determination of calorific value, European Committee for Standardization.

García R., Pizarro C., Lavín A.G., and Bueno J.L., 2012. Characterization of Spanish biomass wastes for energy use. Bior. Technol., 103, 249-258.

Grubor M., Krička T., Voća N., Jurišić V., Bilandžija N., Antonović A., and Matin A., 2015. Utilization of cereal straw for green energy production (in Croatian). Krmiva, 57, 63-68.

Hodgson E.M., Fahmi R., Yates N., Barraclough T., Shield I., Allison G., and Donnison I.S., 2010. Miscanthus as a feedstock for fast-pyrolysis: does agronomic treatment affect quality?. Bior. Technol., 101, 6185-6191.

Howaniec N. and Smoliński A., 2011. Steam gasification of energy crops of high cultivation potential in Poland to hydrogen-rich gas. Int. J. Hydrogen. Energy, 36, 2038-2043.

HRN EN ISO 16948:2015. Solid biofuels - Determination of total content of carbon, hydrogen and nitrogen, Croatian Standard Institute.

HRN EN ISO 16967:2015. Solid biofuels- Determination of major elements- $\mathrm{Al}, \mathrm{Ca}, \mathrm{Fe}, \mathrm{Mg}, \mathrm{P}, \mathrm{K}, \mathrm{Si}, \mathrm{Na}$ and $\mathrm{Ti}$, Croatian Standard Institute.

HRN EN ISO 16968:2015, Solid biofuels - Determination of minor elements, Croatian Standard Institute.

HRN EN ISO 18122:2015. Solid biofuels - Determination of ash content, Croatian Standard Institute.

HRN EN 18134-2:2015. Solid biofuels - Determination of moisturecontentovendrymethod-Part2:Totalmoisture-Simplified method Croatian Standard Institute.

ISO 5351-1:2002. Cellulose in dilute solutions - Determination of limiting viscosity number. International Organization for Standardization.

Jeguirim M., Dorge S., and Trouvé G., 2010. Thermogravimetric analysis and emission characteristics of two energy crops in air atmosphere: Arundo donax and Miscanthus giganteus. Bior. Technol., 101, 788-793.

Jenkins B., Baxter L.L., and Miles T.R., 1998. Combustion properties of biomass. Fuel Proces Technol., 54, 17-46.

Jørgensen H., Bach K.J., and Felby C., 2007. Enzymatic conversion of lignocellulose into fermentable sugars: challenges and opportunities. Biofuels Bioprod. Bioref., 1, 119-134.

Jurišić V., Voća N., Bilandžija N., Krička T., Antonović A., Grubor M., Matin A., and Kontek M., 2017. Pyrolysis properties of major energy crops in Croatia (in Croatian). 51st Croatian and 11th Int. Symp. Agriculture, February 13-17, Dubrovnik, Croatia.

Krička T., Bilandžija N., Jurišić V., Voća N., and Matin A., 2012. Energy analysis of main residual biomass in Croatia. Afr. J. AgricRes., 7, 6383-6388.

Krzywy-Gawrońska E., 2012. The effect of industrial wastes and municipal sewage sludge compost on the quality of 
Virginia fanpetals (Sida Hermaphrodita Rusby) biomass Part 1. Macroelements content and their uptake dynamics. Pol. J. Chem. Technol., 14, 9-15.

Lewandowski I., Clifton-Brown J.C., Andersson B., Basch G., Christian D.G., Jorgensen U., Jones M.B., Riche A.B., Schwarz K.U., Tayebi K., and Texerija F., 2003. Enviroment and harvest time affect the combustion qualities of Miscanthus genotypes. Agron. J., 95: 1274-1280.

Licursi D., Antonetti C., Bernardini J., Cinelli P., Coltelli M. B., Lazzeri A., and Galletti A.M R., 2015. Characterization of the Arundo Donax L. solid residue from hydrothermal conversion: comparison with technical lignins and application perspectives. Ind. Crops Prod., 76, 1008-1024.

Mos M., Banks S.W., Nowakowski D.J., Robson P.R.H, Bridgwater A.V., and Donnison I.S., 2013. Impact of Miscanthus $\mathrm{x}$ giganteus senescence times on fast pyrolysis bio-oil quality. Bio. Techn., 129, 335-342.

Olsen P.O. and Plackett D.V., 1999. Perspectives on the performance of natural plant fibres. Proc. Int. Conf. Natural Fibres Performance Forum, May 27-28, Copenhagen, Denmark.

Quaak P., Knoef H., and Stassen H.E., 1999. Energy from biomass: a review of combustion and gasification technologies (23, 1-78). World Bank Publications, book.

Raspolli Galletti A.M., D'Alessio A., Licursi D., Antonetti C., Valentini G., Galia A., and Nassi o Di Nasso N., 2015. Midinfrared FT-IR as a tool for monitoringherbaceous biomass composition and its conversion to furfural. J. Spectroscopy, 2015, 1-12.
Riffaldi R., Saviozzi A., Cardelli R., Bulleri F., and Angelini L., 2010. Comparison of soil organic matter characteristics under the energy corp giant reed cropping sequence and natural grass. Commun. Soil Sci. Plant Anal., 41, 173-180.

Stolarski M.J., Krzyżaniak M., Śnieg M., Słomińska E., Piórkowski M., and Filipkowski R., 2014. Thermophysical and chemical properties of perennial energy crops depending on harvest period. Int. Agrophys., 28, 201-211.

Šiaudinis G., Jasinskas A., Šarauskis E., Steponavičius D., Karčauskienė D., and Liaudanskienè I., 2015. The assessment of Virginia mallow (Sida hermaphrodita Rusby) and cup plant (Silphium perfoliatum L.) productivity, physico-mechanical properties and energy expenses. Energy, 93, 606-612.

Tao G., Lestander T.A., Geladi P., and Xiong S., 2012. Biomass properties in association with plant species and assortments I: A synthesis based on literature data of energy properties. Renew Sust. Ener. Rev., 16, 3481-3506.

Vargas-Moreno J.M., Callejón-Ferre A.J., Pérez-Alonso J., and Velázquez-Martí B., 2012. A review of the mathematical models for predicting the heating value of biomass materials. Renew Sust. Energ. Revews, 16, 3065-3083.

Vassilev S.V., Baxter D.,Vassileva C.G., and Andersen L.K., 2010. An overview of the chemical composition of biomass. Fuel, 89, 913-933.

Wróblewska H., Komorowicz M., Pawłowski J., and Cichy W., 2009. Chemical and energetical properties of selected lignocellulosic raw materials. Folia For. Pol., 40, 67-78. 